\title{
The Effect of the Quality of Entrepreneurship Education and Students' Participation on Entrepreneurial Competence and Entrepreneurial Intention
}

\author{
Chae-Kwan $\operatorname{Lim}^{1}$ \\ ${ }^{1}$ Professor, Department of Distribution Management, Tongmyong University, Korea, cklim@tu.ac.kr
}

\begin{abstract}
The purpose of this study is to empirically investigate whether the entrepreneurship education conducted by universities affects university students' competence and their entrepreneurial intention. The empirical study was conducted to verify the structural relationship between the quality of entrepreneurship education and students' willingness to participate, entrepreneurial competence and entrepreneurial intention. For this purpose, a survey was conducted on 360 university students in Busan, Ulsan and Gyeongnam Province who experienced entrepreneurship education. The survey took place in parallel with face-to-face and online surveys from early January to late May 2020. The frequency analysis was conducted using SPSS to analyze the status of the data collected through the survey. In addition, reliability analysis and exploratory factor analysis were performed to verify the reliability and validity of the measurement tool, and confirmatory factor analysis, correlation analysis, and structural equation model analysis were conducted to verify the research hypothesis of this study using AMOS. The empirical study was conducted to verify the structural relationship between the quality of entrepreneurship education and students' willingness to participate, entrepreneurial competence and entrepreneurial intention. The results are summarized as follows. First, the quality of entrepreneurship education of universities had a significant positive effect on students' participation in entrepreneurship education. Second, the quality of entrepreneurship education had a significant positive effect on entrepreneurship competence. Third, participation in entrepreneurship education had a significant positive effect on entrepreneurship competence. Fourth, the participation in entrepreneurship education had a significant positive effect on the entrepreneurial intention. Fifth, the entrepreneurial competence had a significant positive effect on entrepreneurial intention. However, the quality of entrepreneurship education did not have a direct and significant effect on the entrepreneurial intention, which showed a contrast. In conclusion, based on the results, the university needs to improve the quality of practical entrepreneurship education and to encourage students to participate actively in entrepreneurship education in order to strengthen their entrepreneurship competence.
\end{abstract}

Keywords: Entrepreneurship Education, Entrepreneurship Education Quality, Entrepreneurship Education Participation, Entrepreneurial Competence, Entrepreneurial Intention

\section{Introduction}

It is back in 2012 that Korean universities started full-scale entrepreneurship education and started supporting student entrepreneurship. At the time, as part of the LINC (Leaders in INdustry-university Cooperation) project for industry-academia cooperation, 'Entrepreneurship Education Center' was established in each university and start-up education and student start-up programs at the center were

Received: February 26, 2021; 1st Review Result: April 12, 2021; 2nd Review Result: May 28, 2021 Accepted: June 30, 2021 
made and supported. Since then, the university's entrepreneurship education has contributed to the expansion of the university's entrepreneurship culture and the creation of a student entrepreneurship ecosystem. In addition, the government and local governments arrange a lot of budget and execute active support for start-up education and entrepreneurship, which is encouraged as a breakthrough in solving youth employment difficulties[1]. For example, the government has conducted start-up support projects targeting universities such as 'Start-up Leading University', 'Cultivation of Leading Universities with Laboratory-based Entrepreneurship', 'Construction of Entrepreneurship System in University', 'Student's Entrepreneurship Team 300 (U-300)', 'Support of Search for Entrepreneurship Associated with Market of Public Service Technology', 'Social Venture', 'Support of Business Incubating Center'. However, despite these efforts, the performance of the programs is still not as expected in that they did not increase students' willingness to make a start-up and improve the entrepreneurial competence and even connect to the actual businesses. In addition, there is a lack of research on measurement and feedback regarding what educational effects these various entrepreneurship education actually achieved, and there is also a lack of research on what factors of entrepreneurship education are increasing entrepreneurship competence and willingness[2][3].

From this point of view, this study is intended to address the problem in the outcome of entrepreneurship education that might change according to the quality of entrepreneurship education and students' participation. Furthermore, the purpose of this study is not only to investigate the qualitative characteristics of university entrepreneurship education but also to structurally prove the fact that participants' willingness and effort in entrepreneurship education may affect entrepreneurship competence and entrepreneurship competence affect entrepreneurship intention.

\section{Literature Review}

\subsection{Concept of Entrepreneurship Education}

Entrepreneurship education is one that teaches the knowledge, function, attitude, and value necessary to start and operate the business successfully. It is defined as a comprehensive concept of education needed to prepare for the actual future entrepreneurship and a process of cultivating entrepreneurship including management skills, attitude and value as a potential worker[4]. This means that entrepreneurship education is a process that provides not only preliminary founders but also potential workers with various learning to help them perform their work in the company. Lee Jae Seok and Lee Sang Myung[5] defined the education as teaching knowledge, function and attitude regarding start-ups necessary to explore business ideas, plan specific business and operate the planned businesses successfully. He thinks of it as an important program and a essential driving force that fosters potential entrepreneurs' will to start up businesses. On the other hand, entrepreneurship education at university is an alternative to career design on the part of students as potential entrepreneurs. It carries out the systemized and organized educational activities which positively affect students' enforcement of mind, knowledge and competence, provide future hopes and visions and realize their hopes by cultivating students' autonomy and creativity as well as a sense of challenge.

Therefore, the goal of entrepreneurship education should not only be to implement entrepreneurship but also to cultivate future talents by developing the ability to learn various competencies and skills and capture business opportunities. In other words, in addition to knowledge and practical skills about startups, it is necessary to design and operate curriculums considering educational purposes that instill positive values for start-ups and improve creative thinking and collaboration ability to develop problem solving capabilities[6]. 


\subsection{Quality of Entrepreneurship Education}

Various studies on quality are actively conducted in the field of education and service, and the definition of quality is used in various meanings and shows differences in the viewpoint of quality according to the fields of each discipline. This study is to apply the category of education as a process for providing intangible services. Service has been recognized as an ambiguous concept due to characteristics such as inhomogeneity and heterogeneity, and non-separation of production and consumption, unlike the type of goods that are easy to objectively evaluate quality. Parasurman et al.[7] said that service quality is a comparison between expectation and performance, service quality evaluation is done not only in the result but also in the evaluation of service providing process, and the service requires relatively high consumer involvement in the consumption process. Also, as consumption occurs at the same time as production, the service providing process, especially the interaction between the service provider and the customer, is important.

In this way, if the quality of entrepreneurship education is defined in terms of service based on the existing study, "it is the degree of discrepancy between the entrepreneurship education actually provided and the perceived education service by receiving the expectation of the students about the entrepreneurship education provided by the university". In other words, if the degree of subjective feeling of the entrepreneurship education service actually received does not reach the level expected before the service is received, the quality of entrepreneurship education is perceived low [8]. This means that the university that provides educational services can change the level of satisfaction of students by grasping the variables that affect the expectation and perceived value of educational services and managing or adjusting them.

\subsection{Participation in Entrepreneurship Education}

The degree of participation in education is a concept that has a deep relationship with class as active and positive attitudes and vibrant characteristics of learners are expressed outside. Recently, as learnercentered or student-centered education is emphasized, it is recognized as an important part of education that students actively participate in education besides the characteristics of the instructor and teachinglearning method. In addition, in-service education staff, education officials, and pedagogists say that active participation in all the curriculum classes is a prerequisite, and the higher the student's participation in the class, the higher the student's academic achievement will be [9]. The participation of education can be defined as motivation, attention, interest, active and positive attitude toward learning, and can be discussed as voluntary learning attitude toward education. The degree of class participation is the cognitive, affective, and behavioral responses that are seen voluntarily and actively before and after the class, and it is also an internal process of learning that shows how much the student contributes to class time.

Therefore, the degree of participation in entrepreneurship education can be divided into that of entrepreneurship education, which is a theoretical entrepreneurship education type in which credits are recognized regardless of major and non-major, and that of entrepreneurship experience, which is a form of practice or experience activities related to entrepreneurship in and out of school[10]. In addition, the participation of entrepreneurship education can be defined as a comprehensive meaning such as students' participation in entrepreneurship education, interest in entrepreneurship education, motivation and experience of entrepreneurship education, acceptance of entrepreneurship education, commitment to education, goal orientation of entrepreneurship education, and desire for achievement. 


\subsection{Entrepreneurial Competence}

Entrepreneurial competence is basically used as one of the various terms for human ability, and the criteria for competence are judged by whether or not they can do the job. The first conceptual definition of competence was made by McClelland(1973) defined as an integrated element combined with knowledge, skills, and attitudes utilized by individuals to perform the tasks assigned within the organization[11]. Meanwhile, the study on entrepreneurial competence was mainly studied as the situation and necessity founders have and it was also centered on their livelihood and opportunity. In the start-up, the entrepreneurs who focus on necessity start a business because there is no alternative or dissatisfied with current job and income, but the entrepreneurs who are opportunity-oriented decide to start up business according to individual's personal desire and choice to take advantage of specific opportunities and pursue self-realization[12]. Söderlund(2008) argued that the entrepreneurial competence is determined by learning and knowledge, and identified that such entrepreneurial competence is a major factor affecting entrepreneurial intention[13]. And Alvarez and Barney[14] have divided pre-founders' start-up competence into management capability, entrepreneur capability, interpersonal capability, and operation capability.

Therefore, increasing the entrepreneurial competence means that positive selection or actual work can be expanded through various experiences or learning, and in that way the entrepreneurial competence is the ability to recognize the opportunity of entrepreneurial success with high possibility of success by preparing in advance.

\subsection{Entrepreneurial Intention}

Entrepreneurship is the process of creating a business organization, and entrepreneurial intention is a psychological state that deals with interest and behavior in start-up[15]. Bae et al.[16] said that the intention to start a business is a desire to own or start his own business by judging the possibility of owning a business. Such entrepreneurial intention is an important variable that has a close relationship with the behavior related to start-up. The will to start a business is not only a self-innovative characteristic, but also a resilience that allows the nation, local economy, or organization to escape from the recession. Entrepreneurship education in university induces students' interest and motivation to start a business and further increases their willingness to start a business.

In fact, the study suggested that it has a positive effect on the entrepreneurial intention on the part of many young people who participated in entrepreneurship education and entrepreneurship support program in university[17]. Kim Yong Tae[18] argued that since knowledge and technology related to start-up are improving pre-founder's motivation and willingness to start a business, practical entrepreneurship education programs such as on-the-job training are needed to promote the willingness for university students to start a business.

The results of previous studies on entrepreneurship education and entrepreneurial intention are summarized as follows: satisfaction with entrepreneurship education affects entrepreneurship intention and increases start-up. Understanding of start-up and entrepreneurial intention are necessary as prerequisites for entrepreneurship.

\section{Methodology}

\subsection{Research Model and Hypothesis}

As a result of analyzing previous studies, it was found that willingness to start a business and entrepreneurial competence are important factors among various factors for success in entrepreneurship. 
Also, it can be observed that although there is an inborn nature of the entrepreneur's competence, most of them can be cultivated through efforts through education. In addition, it was confirmed that entrepreneurship education has contributed to the enhancement of entrepreneurship competence and entrepreneurship willingness. Therefore, it is possible to consider the structural relationship that the entrepreneurship competence will be strengthened according to the entrepreneurship education in universities and students' participation which will affect the entrepreneurship will of the students. In this study, the research model and the research hypothesis were set up as follows to empirically investigate the structural relationship of each relationship based on the previous studies $([1][4][5][19][20])$.

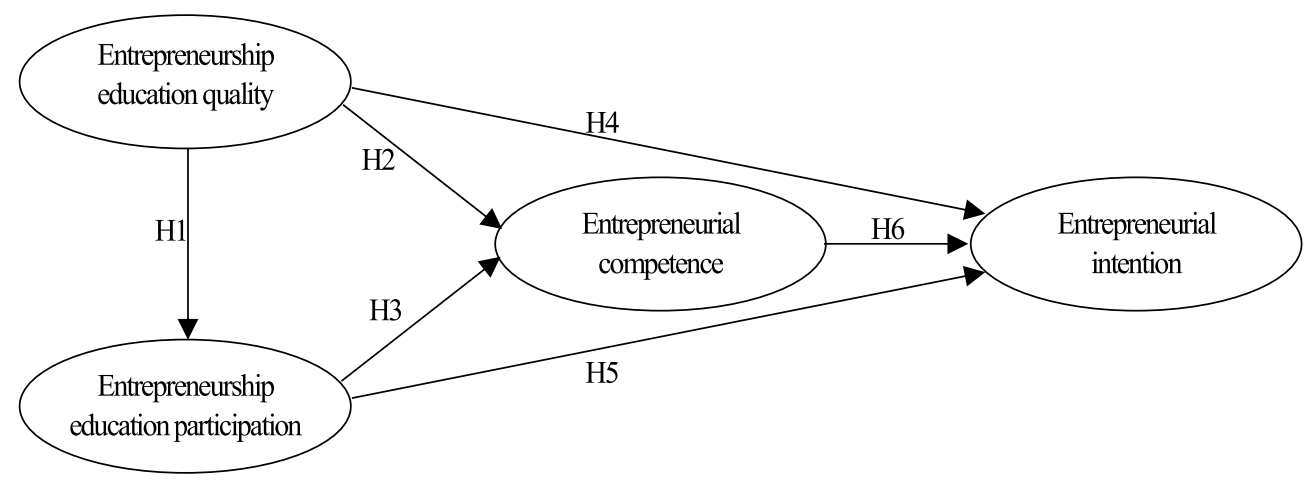

[Fig. 1] Research Model

Based on the above research models, the following hypotheses were set to verify the effects of the quality of entrepreneurship education and the participation in entrepreneurship education on the entrepreneurship competence and entrepreneurship intention on the part of students participating in entrepreneurship education.

Hypothesis 1: The quality of entrepreneurship education in university will have a positive effect on the participation of university students in the education

Hypothesis 2: The quality of entrepreneurship education in university will have a positive effect on students' entrepreneurship competence.

Hypothesis 3: University students' participation in entrepreneurship education will have a positive effect on students' entrepreneurship competence.

Hypothesis 4: The quality of university entrepreneurship education will have a positive effect on students' intention to start a business

Hypothesis 5: The participation of university students in entrepreneurship education will have a positive effect on the students' intention to start entrepreneurship

Hypothesis 6: University students' entrepreneurship competence will have a positive effect on entrepreneurship intention.

\subsection{Research Instrument}

\subsubsection{Quality of Entrepreneurship Education}

This study sees the entrepreneurship education as a curriculum and comparative education conducted by universities that provide knowledge and information on entrepreneurship and enhance entrepreneurship competence and entrepreneurship intention and defines the quality of entrepreneurship education as the level of perception of the education. In addition, seven questions were measured, including 'quality of educators in charge (professor's enthusiasm of teaching and level of preparation)', 
'educational contents', 'educational environment', 'entrepreneurship support space (educational entrepreneurship room and business practice room)', and 'educational materials (video materials, etc.)' among the factors of entrepreneurship education used in the research of Kim Yong Tae[1] and Choi Minjung and Park Jaewha[10].

\subsubsection{Participation in Entrepreneurship Education}

This study defines the participation of entrepreneurship education as a degree of arbitrarily participating in the curriculum (credit recognition course) and comparative programs to cultivate knowledge and entrepreneurial skills necessary for entrepreneurship and entrepreneurship according to the entrepreneurship curriculum provided by universities. Based on the studies of Chung Dae Yong et al.[21], Shekhar et al.[22], 7 items were divided and measured: the degree of participation in entrepreneurship education (motivation of entrepreneurship education and the degree of participation in entrepreneurship special lecture), experience and enthusiasm of entrepreneurship club activities, and degree of entrepreneurship experience (participation in entrepreneurship fair and company tour of startups).

\subsubsection{Entrepreneurial Competence}

The entrepreneurial competence was defined as the knowledge and ability required for performing entrepreneurship. Based on the studies of Mitchelmore and Rowley[23] modified to suit the purpose of this study, the total 6 items were measured by dividing it into achievement competence, creativity competence, social competence, network competence, and interpersonal competence.

\subsubsection{Entrepreneurial Intention}

Entrepreneurial intention is generally defined as the will to start up in the future. It can be also defined as the attitude and the behavior to acquire and understand the information necessary for the start-up based on the strong will and desire for the start-up rather than the employment even if the student who took the start-up education does not implement the start-up. Therefore, this study used the previous studies such as Ke Su and Chae Kwan Lim[19], Mueller and Dato-on[24] and Moon and Choi[25], measured the five items such as preparation for start-up, information collection for start-up, willingness to start-up and intention to start up in the future.

\subsection{Data Collection and Analysis Method}

The empirical study was conducted based on the data collected through the survey. A total of 360 students who had experience in entrepreneurship education at universities in Busan, Ulsan and Gyeongnam Province participated in the survey which took place from early January 2020 to the end of May 2020.

The survey method was conducted in parallel with face-to-face survey and online survey to increase the recovery rate. The frequency analysis was conducted using SPSS 26.0 to analyze the current status of the data collected through the survey. In addition, reliability analysis and exploratory factor analysis were conducted to verify the reliability and validity of the measurement tool, and confirmatory factor analysis, correlation analysis, and structural equation model analysis were conducted to verify the research hypothesis of this study using AMOS 26.0.

\section{Results of the Research}

\subsection{General Status of Data}


The demographic characteristics of the respondents collected for this study are as follows [Table 1].

First, the gender status of the respondents was 55.3\% (199 males) and 44.7\% (161 females) among the total 360 respondents, which means that the proportion of men is higher. Second, the status by grade was analyzed as $8.9 \%$ (32 people) for the first grade, $13.6 \%$ ( 49 people) for the second grade, $25.8 \%$ (93 people) for the third grade, and 51.7\% (186 people) for the fourth grade. Third, in the current status of majors, $32.5 \%$ of engineering (117 people), $24.4 \%$ of social sciences ( 88 people), $18.6 \%$ of arts and physical education ( 67 people), $14.4 \%$ of humanities (52 people), and other (medical health, education, etc.) were in the order of respondents.

[Table 1] Data Characteristics

\begin{tabular}{|c|c|c|c|c|c|c|c|}
\hline \multicolumn{2}{|c|}{ Division } & \multirow{2}{*}{$\begin{array}{c}\text { Frequency } \\
199\end{array}$} & \multirow{2}{*}{$\frac{\text { Ratio }(\%)}{55.3}$} & \multicolumn{2}{|r|}{ Division } & \multirow{2}{*}{$\begin{array}{c}\text { Frequency } \\
117\end{array}$} & \multirow{2}{*}{$\frac{\text { Ratio }(\%)}{32.5}$} \\
\hline \multirow{2}{*}{ Gender } & Male & & & \multirow{5}{*}{ Majors } & Engineering & & \\
\hline & Female & 161 & 44.7 & & Social sciences & 88 & 24.4 \\
\hline \multirow{4}{*}{ Grade } & 1st grade & 32 & 8.9 & & Arts and physical & 67 & 18.6 \\
\hline & 2nd grade & 49 & 13.6 & & Humanities & 52 & 14.4 \\
\hline & 3rd grade & 93 & 25.8 & & Others & 36 & 10 \\
\hline & 4th grade & 186 & 51.7 & & Total & 360 & 100 \\
\hline
\end{tabular}

\subsection{Result of Validity and Reliability Verification}

The reliability analysis and exploratory factor analysis were conducted to verify the reliability and validity of each construct such as the quality of entrepreneurship education, participation in entrepreneurship education, entrepreneurial competence and entrepreneurial intention. First, reliability analysis was conducted using Cronbach's coefficient, which is a method to confirm the internal consistency of each research unit, and variables with a total correlation value of .4 or more were used for analysis. In addition, in order to verify the validity of componential concept of the measurement items, factor analysis was conducted by extracting the main component factors and by the rotation of Varimax, which is the orthogonal rotation method, and it was used for analysis based on the factors with the eigenvalue of 1.0 or more. The results of exploratory factor analysis for reliability and validity verification are as follows [Table 2].

[Table 2] Result of Reliability and Validity Analysis

\begin{tabular}{|c|c|c|c|c|c|c|}
\hline Component & $\begin{array}{c}\text { Entrepreneurship } \\
\text { education } \\
\text { participation }\end{array}$ & $\begin{array}{l}\text { Entrepreneurship } \\
\text { education quality }\end{array}$ & $\begin{array}{l}\text { Entrepreneurial } \\
\text { competence }\end{array}$ & $\begin{array}{l}\text { Entrepreneurial } \\
\text { intention }\end{array}$ & Commonality & $\begin{array}{c}\text { Cronbach } \\
\alpha\end{array}$ \\
\hline $\begin{array}{l}\text { Participation } 4 \\
\text { Participation } 6 \\
\text { Participation } 2 \\
\text { Participation } 5 \\
\text { Participation } 7 \\
\text { Participation } 3 \\
\text { Participation } 1\end{array}$ & $\begin{array}{l}.800 \\
.715 \\
.714 \\
.693 \\
.677 \\
.676 \\
.646 \\
\end{array}$ & $\begin{array}{l}.149 \\
.097 \\
.221 \\
.018 \\
.273 \\
.317 \\
.201 \\
\end{array}$ & $\begin{array}{l}.143 \\
.060 \\
.162 \\
.002 \\
.245 \\
.250 \\
.171 \\
\end{array}$ & $\begin{array}{l}.131 \\
.247 \\
.235 \\
.243 \\
.127 \\
.199 \\
.196\end{array}$ & $\begin{array}{l}.699 \\
.585 \\
.641 \\
.539 \\
.609 \\
.659 \\
.525\end{array}$ & .8834 \\
\hline $\begin{array}{l}\text { Education quality } 2 \\
\text { Education quality } 4 \\
\text { Education quality } 5 \\
\text { Education quality } 6 \\
\text { Education quality } 3 \\
\text { Education quality } 1\end{array}$ & $\begin{array}{l}.137 \\
.187 \\
.142 \\
.133 \\
.095 \\
.344 \\
\end{array}$ & $\begin{array}{l}.842 \\
.798 \\
.772 \\
.759 \\
.744 \\
.673 \\
\end{array}$ & $\begin{array}{l}.113 \\
.131 \\
.082 \\
.209 \\
.072 \\
.207\end{array}$ & $\begin{array}{l}.061 \\
.130 \\
.133 \\
.109 \\
.054 \\
.033 \\
\end{array}$ & $\begin{array}{l}.744 \\
.705 \\
.641 \\
.649 \\
.570 \\
.615\end{array}$ & .8887 \\
\hline $\begin{array}{l}\text { Competence } 4 \\
\text { Competence } 3 \\
\text { Competence } 6 \\
\text { Competence } 1 \\
\text { Competence } 2 \\
\text { Competence } 5\end{array}$ & $\begin{array}{l}.097 \\
.055 \\
.139 \\
.240 \\
.102 \\
.164\end{array}$ & $\begin{array}{l}.176 \\
.129 \\
.204 \\
.043 \\
.012 \\
.249\end{array}$ & $\begin{array}{l}.760 \\
.728 \\
.721 \\
.716 \\
.714 \\
.702\end{array}$ & $\begin{array}{l}.276 \\
.139 \\
-.079 \\
.195 \\
.130 \\
.148\end{array}$ & $\begin{array}{l}.694 \\
.569 \\
.588 \\
.610 \\
.538 \\
.604\end{array}$ & .8555 \\
\hline $\begin{array}{l}\text { Intention } 1 \\
\text { Intention } 2 \\
\text { Intention } 4 \\
\text { Intention } 3\end{array}$ & $\begin{array}{l}.268 \\
.247 \\
.335 \\
.375\end{array}$ & $\begin{array}{l}.128 \\
.161 \\
.076 \\
.128\end{array}$ & $\begin{array}{l}.150 \\
.210 \\
.204 \\
.197\end{array}$ & $\begin{array}{l}.825 \\
.788 \\
.763 \\
.717\end{array}$ & $\begin{array}{l}.791 \\
.751 \\
.741 \\
.710\end{array}$ & .8892 \\
\hline
\end{tabular}




\begin{tabular}{|c|c|c|c|c|c|}
\hline Eigen value & 8.688 & 2.559 & 2.235 & 1.293 & \\
Variance (\%) & 37.775 & 11.126 & 9.716 & 5.623 & \\
Cum. variance (\%) & 37.775 & 48.901 & 58.617 & 64.240 & \\
\hline \multicolumn{7}{|c|}{ Kaiser-Meyer-Olkin Measure of Sampling Adequacy $=.902$} \\
\hline \multicolumn{7}{|c|}{ Bartlett's Test of Sphericity, Approx. $\chi^{2}=4,874.959$, degree of freedom (d.f)=78, Sig. $\mathrm{p}=.000$} \\
\hline
\end{tabular}

As shown in the table, exploratory factor analysis showed that four factors were extracted, and these four factors explained $64.24 \%$ of the total variance. The KMO (Kaiser-Meyer-Olkin) measure indicating the suitability of the factorial analysis is .902 , indicating that the selection of variables for the factorial analysis is desirable. Based on Batlett's spherical verification $\chi^{2}=4,874.959$, degrees of freedom $=78$, and significance value $\mathrm{p}=.000$, there is a common factor.

As a result of factor analysis, factor 1 was found to be the participation in entrepreneurship education, factor 2 was the quality of entrepreneurship education, factor 3 was the entrepreneurship competence, and factor 4 was the entrepreneurship intention. As shown in the table, the reliability analysis showed that Cronbach' $\alpha$ value which shows internal consistency was $\alpha=.883$ for participation in entrepreneurship education, $\alpha=.888$ for entrepreneurship education quality, $\alpha=.855$ for entrepreneurial competence, and $\alpha=.889$ for entrepreneurial intention.

\subsection{Confirmatory Factor Analysis}

Confirmatory factor analysis was conducted to verify the convergent validity of all research units included in this research model. In this study, the value of the individual measurement items of the theoretical variables was used, and the scale was refined based on the co-variance modification index of 10 or more of the measurement item error. As a result, the scale was set for each of the factors of 'participation in entrepreneurship education' and 'entrepreneurship competence', and the result of confirmatory factor analysis is as follows [Table 3].

[Table 3] Result of Confirmatory Factor Analysis

\begin{tabular}{|c|c|c|c|c|c|c|c|c|c|c|c|c|}
\hline \multicolumn{2}{|c|}{$\begin{array}{l}\text { Conceptual } \\
\text { variable }\end{array}$} & \multicolumn{2}{|c|}{ Varables } & $\begin{array}{c}\text { Reg. } \\
\text { Estimate }\end{array}$ & \multicolumn{2}{|c|}{$\begin{array}{l}\text { Std. Reg. } \\
\text { Estimate }\end{array}$} & S. E. & & $t$ & \multicolumn{2}{|c|}{$\begin{array}{l}\text { Composite } \\
\text { Reliability } \\
\text { (CR) }\end{array}$} & $\begin{array}{l}\text { Average } \\
\text { Variance } \\
\text { Extracted } \\
\text { (AVE) }\end{array}$ \\
\hline \multirow{6}{*}{\multicolumn{2}{|c|}{$\begin{array}{l}\text { Entrepreneurship } \\
\text { education quality }\end{array}$}} & \multicolumn{2}{|c|}{ Education quality 1} & .926 & \multicolumn{2}{|c|}{.730} & .060 & \multicolumn{2}{|c|}{15.465} & \multirow{6}{*}{\multicolumn{2}{|c|}{.925}} & \multirow{6}{*}{.675} \\
\hline & & Education & lality 2 & 1.000 & \multicolumn{2}{|c|}{.857} & - & \multicolumn{2}{|c|}{-} & & & \\
\hline & & \multicolumn{2}{|c|}{ Education quality 3} & .796 & \multicolumn{2}{|c|}{.693} & .056 & \multicolumn{2}{|c|}{14.328} & & & \\
\hline & & \multicolumn{2}{|c|}{ Education quality 4} & .918 & \multicolumn{2}{|c|}{.784} & .054 & \multicolumn{2}{|c|}{16.976} & & & \\
\hline & & \multicolumn{2}{|c|}{ Education quality 5} & .818 & \multicolumn{2}{|c|}{.682} & .059 & \multicolumn{2}{|c|}{13.764} & & & \\
\hline & & \multicolumn{2}{|c|}{ Education quality 6} & .773 & \multicolumn{2}{|c|}{.718} & .051 & \multicolumn{2}{|c|}{15.088} & & & \\
\hline \multirow{6}{*}{\multicolumn{2}{|c|}{$\begin{array}{l}\text { Entrepreneurship } \\
\text { education } \\
\text { participation }\end{array}$}} & \multicolumn{2}{|c|}{ Participation 2} & .867 & & & .055 & \multicolumn{2}{|c|}{15.777} & \multirow{6}{*}{\multicolumn{2}{|c|}{.916}} & \multirow{6}{*}{.647} \\
\hline & & \multicolumn{2}{|c|}{ Participation 3} & 1.000 & \multicolumn{2}{|c|}{.844} & - & & - & & & \\
\hline & & Partici & on 4 & .883 & & & .053 & & 629 & & & \\
\hline & & Partici] & on 5 & .803 & & & .072 & & 125 & & & \\
\hline & & Partici] & on 6 & .826 & & & .066 & & 617 & & & \\
\hline & & Partici] & on 7 & .851 & & & .059 & & 459 & & & \\
\hline & & Compe & ce 1 & .880 & & & .064 & & 654 & & & \\
\hline & & Compe & ce 2 & .727 & & & .059 & & 302 & & & \\
\hline Entrepre & urial & Compe & ce 3 & .805 & & & .061 & & 197 & .90 & & .653 \\
\hline & & Compe & ce 4 & 1.000 & & & - & & - & & & \\
\hline & & Compe & ce 6 & .612 & & & .057 & & 809 & & & \\
\hline & & Inten & & 1.000 & & & - & & - & & & \\
\hline Entrepre & urial & Inten & & .918 & & & .051 & & 915 & & & \\
\hline inten & n & Inten & & .935 & & & .050 & & 816 & .91 & & .119 \\
\hline & & Inten & & .939 & & & .054 & & 427 & & & \\
\hline$\chi^{2}$ & d.f. & $\mathrm{P}$ & $\chi^{2 / \text { d.f. }}$ & RMR & GFI & AGFI & NFI & RFI & IFI & TLI & CFI & RMSEA \\
\hline 319.135 & 167 & .000 & 1.911 & .032 & .925 & .897 & .926 & .907 & .963 & .954 & .963 & .050 \\
\hline
\end{tabular}


As a result of analyzing the confirmatory factor on the theoretical variables such as the quality of entrepreneurship education, participation in entrepreneurship education, entrepreneurship competence and entrepreneurship intention, the fit index appeared as RMR (.032) $\leq .05$, GFI (.925) $\geq .90$, AGFI $(.897) \geq .80$, NFI $(.926) \geq .90$, CFI $(.963) \geq .90$, and RMSEA $(.05) \leq .05$ as shown in the table. The overall fit index was found to be appropriate. In addition, when evaluating the representativeness of the scales used for each factor, composite reliability (CR) and average variance extracted (AVE) among the research units showed higher construct reliability of each research unit than 0.7 as a general standard, and AVE value was higher than 0.5. Convergent validity was verified because it can be said that the items used in this study have representativeness for research units.

\subsection{Correlation Analysis between Constructs}

In order to verify the discriminant validity between each factors whose convergent validity was verified by the confirmatory factor analysis results, correlation analysis between each factors was conducted, and the results are the same as [Table 4].

[Table 4] Result of Correlation Analysis

\begin{tabular}{|c|c|c|c|c|}
\hline Constracts & $\begin{array}{c}\text { Entrepreneurship } \\
\text { education quality }\end{array}$ & $\begin{array}{c}\text { Entrepreneurship } \\
\text { education } \\
\text { participation }\end{array}$ & $\begin{array}{c}\text { Entrepreneurial } \\
\text { competence }\end{array}$ & $\begin{array}{c}\text { Entrepreneurial } \\
\text { intention }\end{array}$ \\
\hline Entrepreneurship education quality & $.675(.821)$ & & & \\
\cline { 1 - 2 } Entrepreneurship education participation & $.519^{* * *}$ & $.647(.804)$ & & \\
\hline Entrepreneurial competence & $.393^{* * *}$ & $.453^{* * *}$ & $.653(.808)$ & \\
\hline Entrepreneurial intention & $.517^{* * *}$ & $.666^{* * *}$ & $.391^{* * *}$ & $.719(.848)$ \\
\hline
\end{tabular}

※ The diagonal value is the AVE index. The values inside $(\quad$ ) is square root values.

$* * * \mathrm{p}<.01$

For the correlation analysis between variables, AMOS analysis was used as the correlation coefficient most widely used for correlation or covariance calculation between variables.

The results of this study showed that the quality of entrepreneurship education, participation in entrepreneurship education, entrepreneurship competence and entrepreneurship intention were all positive $(+)$ at the significance level of .01 , which was consistent with the relationship between the research model and the research units presented in the research hypothesis. In addition, the result of verification of discrimination validity by comparing the square value of correlation with AVE showed that AVE is more than 0.5 and is larger than the square value of correlation, so it was analyzed that there is discriminant validity.

\subsection{Results of the Hypothesis Test}

This study is to understand the structural causal relationship between the quality of university entrepreneurship education, university students' participation in the education, entrepreneurship competence, and entrepreneurship intention. The result of verifying the overall structural model between each variable and the hypothesis verification result are as follows [Table 5] and [Fig. 2].

As a result of examining the overall structural model of the research units such as the quality of entrepreneurship education, participation in entrepreneurship education, entrepreneurship capacity, and entrepreneurship intention used in this study, $\chi^{2}=61.608$ (d.f. $=35, p=.004$ ), $\chi^{2} /$ d.f. $=1.760, R M R=.019$, $\mathrm{GFI}=.968, \mathrm{AGFI}=.940, \mathrm{NFI}=.965, \mathrm{CFI}=984$, and $\mathrm{RMSEA}=.047$ were derived, which means the structural model was statistically appropriate. 
[Table 5] Result of Hypothesis Test

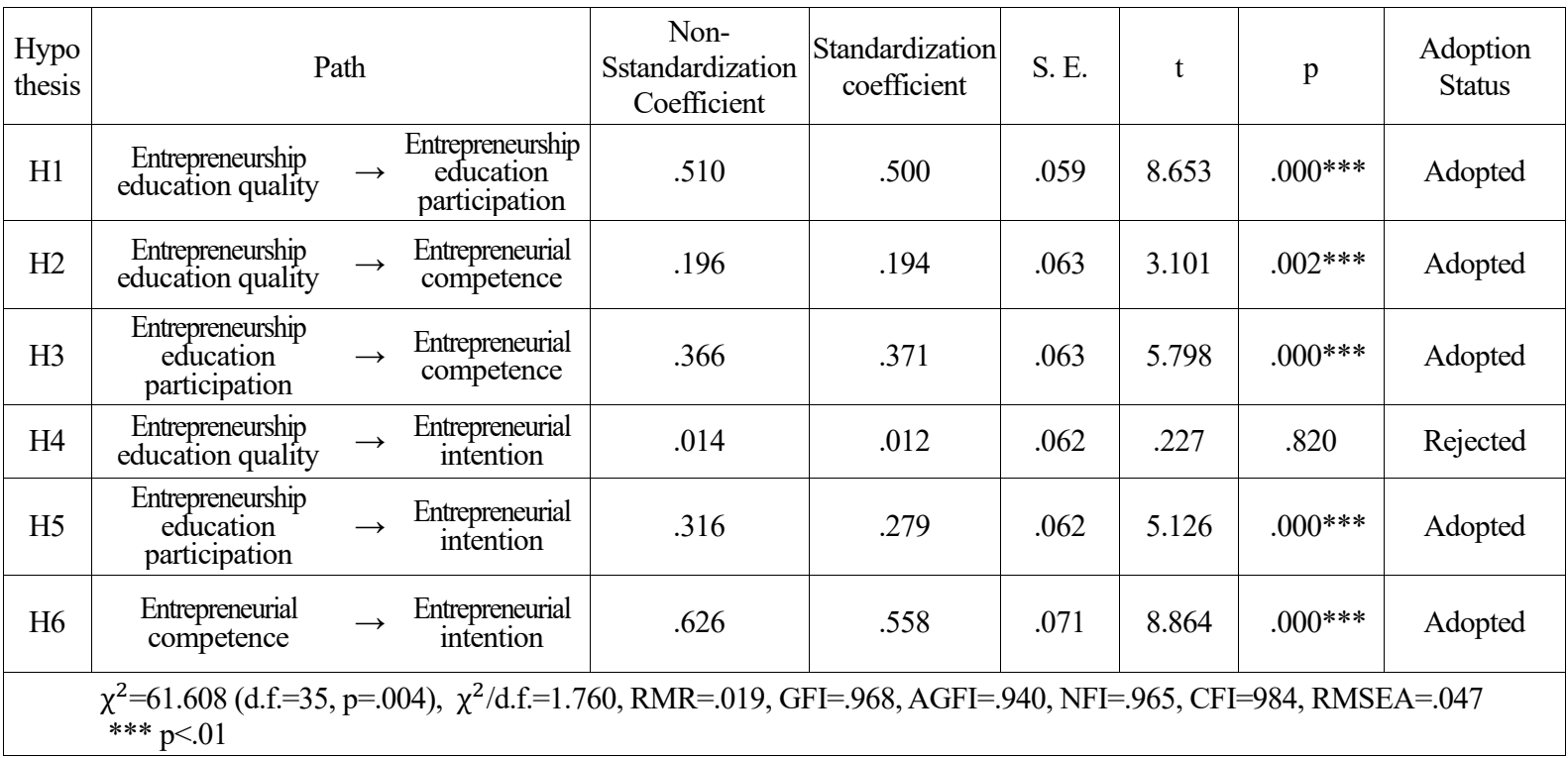

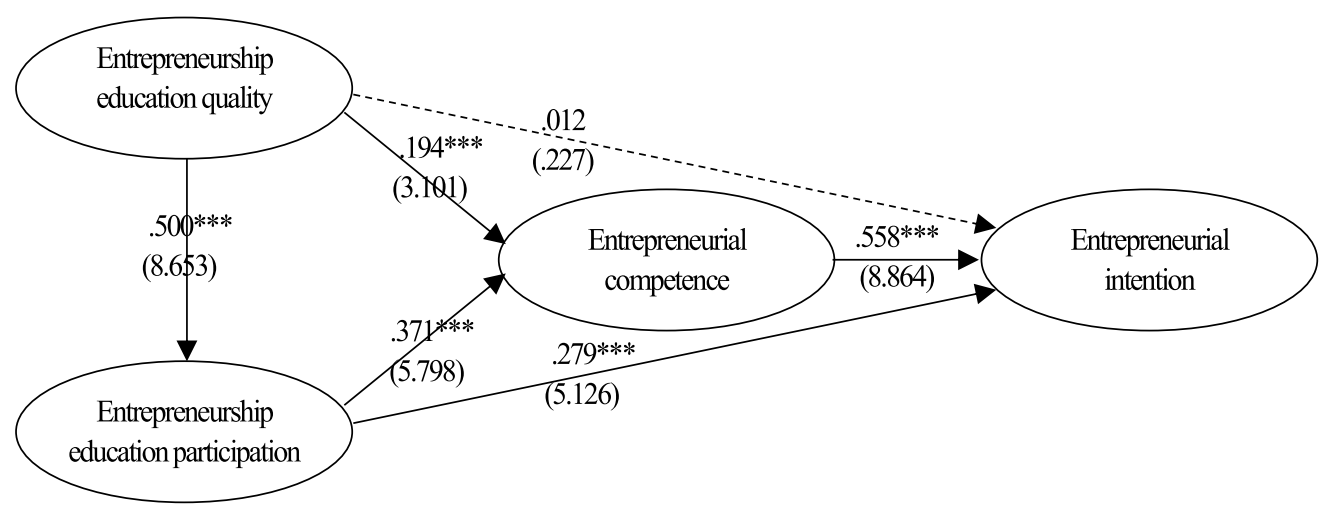

[Fig. 2] Result of Hypothesis Test

In addition, the results of the research hypothesis verification on the structural relationship between the quality of entrepreneurship education, participation in entrepreneurship education, entrepreneurship competence and entrepreneurship intention are as follows.

First, as a result of verifying hypothesis 1 to see if the quality of entrepreneurship education has a significant effect on the participation of entrepreneurship education, the standardization coefficient was $.500, t=8.653(\mathrm{p}=.000)$, which was statistically significant at the significance level .01 , so hypothesis 1 was adopted. Second, as a result of verifying hypothesis 2 to see if the quality of entrepreneurship education has a significant effect on entrepreneurship competence, the standardization coefficient was $.194, t=3.101 \quad(p=.002)$, which was statistically significant at the significance level .01 , so Hypothesis 2 was adopted. Third, as a result of verifying hypothesis 3 to see if participation in entrepreneurship education has a significant effect on entrepreneurship competence, the standardization coefficient was $.371, \mathrm{t}=5.798(\mathrm{p}=.000)$, which was statistically significant at the significance level .01 , and hypothesis 3 was adopted. Fourth, as a result of verifying hypothesis 4 to see if the quality of entrepreneurship education has a significant effect on the intention to start a business, the standardization coefficient was $.012, \mathrm{t}=.227(\mathrm{p}=.820)$, which was not statistically significant, and hypothesis 4 was rejected. Fifth, as a result of verifying hypothesis 5 to see if participation in entrepreneurship education has a significant effect on entrepreneurship intention, the standardization coefficient was $.279, \mathrm{t}=5.126$ 
$(\mathrm{p}=.000)$, which was statistically significant at the significance level .01 , so hypothesis 5 was adopted. Finally, as a result of verifying hypothesis 6 to see if entrepreneurial competence has a significant effect on entrepreneurial intention, the standardization coefficient was $.558, \mathrm{t}=8.864(\mathrm{p}=.000)$, which was statistically significant at the significance level .01, so hypothesis 6 was adopted.

\section{Conclusion}

In order for university students to start a successful business after graduating and entering society, it is necessary to make efforts to establish their competence as a founder through systematic education and various experiences during college. In the meantime, universities and government agencies in Korea have made a lot of efforts to educate and support for start-ups in addition to employment education in the direction of another career path for university students. From this point of view, this study empirically investigated how much performance the entrepreneurship education of the university promoted recently in the practical direction is achieved. For this purpose, a survey was conducted on 360 students who had taken entrepreneurship education at universities in Busan, Ulsan and Gyeongnam area, and based on this, the structural relationship between entrepreneurship education quality, entrepreneurship education participation, entrepreneurship ability and entrepreneurship intention was empirically investigated.

Based on the result of the study, it was found that the quality of entrepreneurship education had a significant effect on the participation of entrepreneurship education, and the quality of entrepreneurship education and participation in entrepreneurship education had a significant effect on the enhancement of entrepreneurship competence and the intention of entrepreneurship. Furthermore, it was confirmed that there was a direct and indirect significant relationship among these individual factors. Also, it was confirmed that there was no direct influence relationship between the quality of entrepreneurship education and the intention to start a business.

In conclusion, it is important to educate entrepreneurs to succeed in starting a business, and it is necessary to educate entrepreneurs to improve their entrepreneurial competence and to continuously enhance their willingness to start a business. In addition, it was empirically verified that the more positive and active the participation intention of entrepreneurship education, the more the entrepreneurial competence and the entrepreneurial intention are increased. Therefore, in order to improve university students' entrepreneurial will, it is necessary to educate entrepreneurial mind-set to enhance entrepreneurship from a long-term perspective. In addition, it is necessary to make proactive efforts of universities to improve practical knowledge and skills necessary for entrepreneurship and to provide field-oriented education and experiential learning.

However, it should not be forgotten that entrepreneurship education is not only an education to implement entrepreneurship, but also an education to cultivate future talents that enhance students' creativity and problem solving ability. As seen above, this study provides implications to the educational field by empirically identifying how much the university's entrepreneurship education has achieved recently. However, the subjects of this study are limited to some universities in Busan, Ulsan and Gyeongnam area, which has a limitation that the representativeness of the sample is low. Therefore, it is necessary to carry out follow-up studies such as expanding the target area of the study and the target of entrepreneurship education in the future.

\section{Acknowledgments}

This Research was supported by the Tongmyong University Research Grants 2019 (2019A029) 


\section{References}

[1] Y. T. Kim, The Effects of Entrepreneurship Education, Entrepreneurial Competence and Attitude on Undergraduate Entrepreneurial Intention, Asia-Pacific Journal of Business Venturing and Entrepreneurship, (2017), Vol.12, No.2, pp.13-20.

[2] An Gi-Don, Lee Taek-Ku, A Study of Facilitating Korean Youth Startup by Analyzing the U.S. and Korean University Startup Ecosystem, Korean Business Education Review, (2018), Vol.33, No.2, pp.401-422, DOI : 10.23839/kabe.2018.33.2.401

[3] Ka Hye Young, The Effect of University Student's Entrepreneurial Competencies on Entrepreneurial Intention: Moderating Effect of Social values, Journal of the Korean Entrepreneurship Socieity, (2021), Vol.16, No.2, pp.119134, DOI : $10.24878 /$ tkes.2021.16.2.119

[4] M. J. Manimala, P. Thomas, Entrepreneurship Education: Innovations and Best Practices, Entrepreneurship Education, Entrepreneurship Education, (2017), pp.3-53, DOI:10.1007/978-981-10-3319-3_1

[5] Lee Jae Seok, Lee Sang Myung, The Relationship between Entrepreneurial Education and Entrepreneurial Intentions: Focusing on Moderating Effects of Entrepreneurial Orientation and Environmental Factors, Asia-Pacific Journal of Business Venturing and Entrepreneurship, (2015), Vol.10, No.3, pp.61-74, DOI : 10.16972/apjbve.10.3.201506.61

[6] R. J.Testa, J. Habarth, J. Peta, K. Balsam, W. Bockting, Development of the Gender Minority Stress and Resilience Measure, Psychology of Sexual Orientation and Gender Diversity, (2015), Vol.2, No.1, pp.65-77, https://doi.org/10.1037/sgd0000081

[7] A. P. Parasuraman, V. A. Zeithaml, L. L. Berry, SERVQUAL: A Multiple Item Scale for Measuring Consumer Perception of Service Quality, Journal of Retailing, (1988), Vol.64, No.1, pp.12-40.

[8] Lee Woo-Jin, Ki Jin-Soo, Kim Yong-Tae, An Empirical Study on the Influence of Entrepreneurship Education Quality and Satisfaction to University Student's Entrepreneurial Intention, Korea Business Education Review, (2013), Vol.28, No.3, pp.105-131, UCI : G704-001274.2013.28.3.003

[9] Yun Gilock, The Effects of a Disability Awareness Instructional Program on Academic Engagement and Acceptance Attitude of Disability of Elementary School Students, Graduate School of Education Korea National University of Education, Doctoral Dissertation, (2014)

[10] Choi Minjung, Park Jaewhan, The Effect of Entrepreneurship Education on Opportunity Recognition and Evaluation: A Focus on Small Business Entrepreneurs, Asia-Pacific Journal of Business Venturing and Entrepreneurship, (2017), Vol.12, No.3, pp.135-146, DOI: 10.16972/apjbve.12.3.201706.135

[11] A. Chwolka, M. G. Raith, The Value of Business Planning before Start-Up-A Decision-Theoretical Perspective, Journal of Business Venturing, (2012), Vol.27, No.3, pp.385-399, https://doi.org/10.1016/j.jbusvent.2011.01.002

[12] D. Smallbone, F. Welter, The Role of Government in SME Development in Transition Economies, International Small Business Journal, (2001), Vol.19, No.4, pp.63-77, https://doi.org/10.1177/0266242601194004

[13] Choi Dae Soo, Sung Chang Soo, Effect of Entrepreneurial Competencies on Entrepreneurial Intention: IT Competency, Creativity Competency, Social Competency, Market Perception Competency, Asia-Pacific Journal of Business Venturing and Entrepreneurship, (2017), Vol.12, No.1, pp.101-109, DOI : 10.16972/apjbve.12.1.201702.101

[14] S. A. Alvarez, J. B. Barney, Resource based Theory and the Entrepreneurial Firm, Strategic Entrepreneurship: Creating a New Mindset, (2017), pp.89-105, https://doi.org/10.1002/9781405164085.ch5

[15] A. Davila, G. Foster, N. Jia, Building Sustainable High-growth Startup Companies: Management Systems as an Accelerator, California Management Review, (2010), Vol.52, No.3, pp.79-105, https://doi.org/10.1525/cmr.2010.52.3.79

[16] T. J. Bae, S. S. Qian, R. Garrett, The Effect of Soliciting Advice in Pre-Start Up Phase on Venture's Speeding Products to Market, Frontiers of Entrepreneurship Research, (2014), Vol.34, No19, pp.3-15.

[17] Jo In-Seog, Oh Hee-Hwa, The Effects of Entrepreneurship on the Entrepreneurial Intention of University Students: Focusing on the Mediating Effects of Entrepreneurship Education Satisfaction and the Moderating Effects of 
Entrepreneurial Support System, Journal of Distribution and Management Research, (2019), Vol.22, No6, pp.87-102, DOI : $10.17961 /$ jdmr.22.06.201912.87

[18] Y. T. Kim, A Comparative Study of Entrepreneurial Motivation, Entrepreneurship and Entrepreneurial Intention between the Students of Experiential Entrepreneurship Class and Theory Centered Class, Asia-Pacific Journal of Business Venturing and Entrepreneurship, (2018), Vol.13, No.4, pp.49-58, DOI : 10.16972/apjbve.13.4.201808.49

[19] Ke Su, Chae-Kwan Lim, The Effects of Entrepreneurship Education on Job Value, Entrepreneurial Self-Efficacy and Entrepreneurial Intention, Turkish Journal of Computer and Mathematics Education, (2021), Vol.12, No.10, pp.951960, https://doi.org/10.17762/turcomat.v12i10.4275

[20] Chae-Kwan Lim, Feng Jing, Influence of Equity and Quality of Legal Service Affecting Trust, Perceived Risk and Behabioral Intention, Asia Life Sciences, (2018), Vol.15, No.3, pp.1443-1459.

[21] Chung Dae-Yong, Yang Jun-Hwan, Kim Chun-Kwang, Influence of Self-Efficacy and Entrepreneurial Participation on Entrepreneurial Intention: Focused on Chinese Students, Korean Business Education Review, (2013), Vol.28, No.5, pp. 545-574, UCI : G704-001274.2013.28.5.019

[22] P. Shekhar, A. H. Saad, J. Libarkin, Understanding Student Participation in Entrepreneurship Education Programs: A Critical Review, International Journal of Engineering Education, (2018), Vol.34, No.3, pp.1060-1072.

[23] S. Mitchelmore, J. Rowley, Entrepreneurial Competencies of Women Entrepreneurs Pursuing Business Growth, Journal of Small Business and Enterprise Development, (2013), Vol.20, No1, pp.125-142, DOI: $10.1108 / 14626001311298448$

[24] S. L. Mueller, M. C. Dato-on, A Cross Cultural Study of Gender-role Orientation and Entrepreneurial Self-efficacy, International Entrepreneurship and Management Journal, (2013), Vol.9, No.1, pp.1-20, DOI:10.1007/s11365-011$0187-\mathrm{y}$

[25] K. S. Moon , S. K. Choi, The Effects of Core Self-Evaluation on Entrepreneurial Intention and Job Searching Stress, International Journal of IT-based Social Welfare Promotion and Management, (2018), Vol.5, No.1, pp.31-36. 